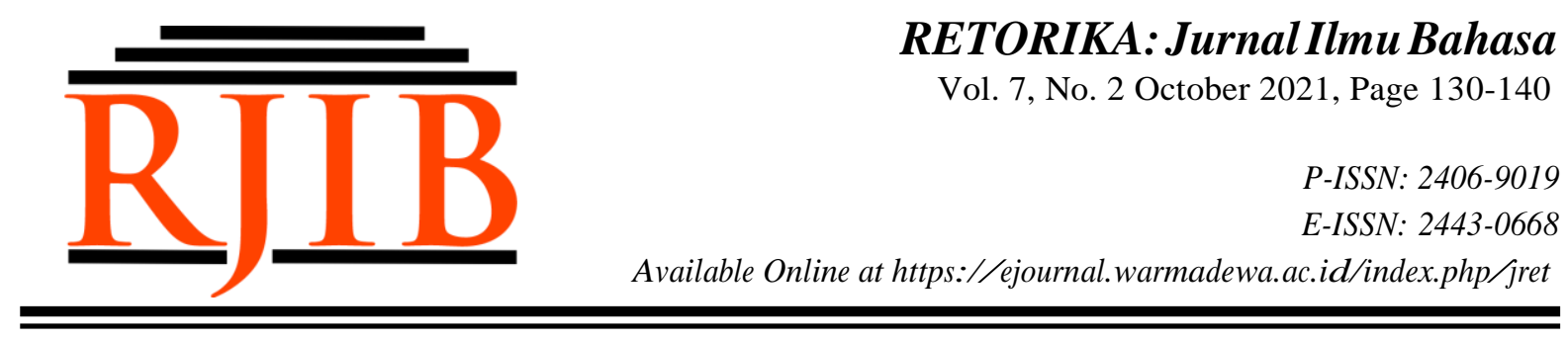

\title{
Syntactic Analysis of Chinese Imperative Function in "The Captain" Movie
}

\author{
Cintiawinata Jung, Julina \& Rudiansyah \\ Chinese Literature Program, Faculty of Cultural Sciences, University of Sumatera Utara \\ cintiawinata99@gmail.com
}

\begin{abstract}
This article analyzes the function of imperative sentences contained in the "The Captain" movie by applying Zhang's theory of imperative sentence function. The research method used is descriptive qualitative research methods. The data source in this research is the 2019 China movie“The Captain” (中国机长 Zhōngguó Jīzhăng). The data are imperative words and sentences in the movie. The data collection technique used was the observation and note technique according to Mahsun, then used the data analysis technique of Miles and Huberman. Researchers found 281 imperative sentences in "The Captain" movie and analyzes the imperative function. The most widely used imperative function is the commanding function, which is 80 sentences. Meanwhile, the least function used was threatening function only 1 sentence. The commanding function is more dominant than other functions and found in the conversations between officers to passengers, flight attendants to passengers, communication between officers and others. The commanding function is also mostly found in the officer's conversations, especially when they were facing an emergency situation. Meanwhile, the words used by the officers, flight attendants and the captain wereshowing respect and courtesy. So that the threathening function was less found in this movie. There are no requesting and begging functions because this movie tells about the incident of the Sichuan flight 8633, including the service of the aircraft officers and the confidence of the officers in facing the emergency situation at that time.
\end{abstract}

Keywords: Syntax Analysis; Imperative Sentences; China Movie; The Captain; Imperative Functions

\section{INTRODUCTION}

In our daily lives, we use language as a means of communication to interact with people around us. There are so many languages that are used to communicate in this world, including: Indonesian, English, Mandarin, Japanese, Arabic, French and many more. The study of language is called linguistics. The object of linguistic study is language. Language according to Kridalaksana in (Chaer, 2007) "language is a system of arbitrary sound symbols 'not fixed', which are used by members of social groups to cooperate, communicate and identify themselves." In this case, it means that language does not have a direct, obligatory relationship between the symbol and the symbol so that language is the result of an agreement between speakers of languages in a society.

Along with the very rapid development of China's economy, Indonesians are interested in learning the country's language, namely Mandarin. If someone can communicate in Mandarin, that means that person has also learned the grammar. The study of grammar is syntax. According to (Kridalaksana, 2001), syntax is a branch of linguistics that studies the arrangement and relationships between words and words, or between words and larger units, or between larger units in language. This means that syntax is a branch of linguistics that studies the relationship between word units from 
phrases, clauses to sentences. Sentence is a language unit that is relatively independent, has a final intonation pattern and consists of clauses.

(Alwi, 2003) states that the type of sentence according to the syntax consists of declarative sentences, interrogative sentences, exclamative sentences and imperative sentences. Declarative sentences are sentences in the form of statements which can be in the form of narration, argumentation, information or description. An interrogative sentence or an interrogative sentence is basically distinguished from the question mark that accompanies the sentence. The contents of the exclamation expressed a feeling of awe and wonder. Meanwhile, the imperative sentence is fully emphasized on the command whose reference point is more to the object in question.

The researcher chose imperative sentences as the object of research because imperative sentences have various functions. Imperative sentences generally function to order someone to do something. When collecting research data, the researcher found that imperative sentences also served to provide suggestions, beg, give warnings and so on. This makes researchers interested in researching imperative sentences.

The use of imperative sentences is of course very common in movies. A movie is a work of art in the form of a series of live images that are played to produce a moving image that is served as a form of entertainment. One of them is the famous movie in 2019, namely “The Captain” movie (中国机长 Zhōngguó Jīzhăng). The Captain is a Chinese drama movie directed by Andrew Lau. The movie was released in China on September 30, 2019. The use of imperative sentences is found in the dialogue between characters, be it between pilots and co-workers, between airplane passengers and between flight attendants. "The Captain" movieteaches the moral values of life to always respect life, respect work and invites the audience to obey the rules that have been made.

According to Seruya Newspaper (December 2019), the movie is based on the Sichuan Airlines Flight 8633 incident.The movie depicts one of the most magical emergency landings in contemporary Chinese aviation history. Liu Chuanjian, a Sichuan Airlines captain carrying 119 passengers and 9 crew members home safely after his plane's windshield shattered and finally shattered on his way from Chongqing in southwest China to Lhasa on May 14, 2018.

The following are some examples of

Mandarin imperative sentences found in "The Captain" movie:

(1)

$$
\begin{aligned}
& \text { 服务员: } \\
& \text { Fúwùyuán: } \\
& \text { 老婆（乘客 别看手机了, 行吗? } \\
& \text { ): } \\
& \text { Lăopó } \\
& \text { (chéngkè): } \\
& \text { Wife } \\
& \text { (passenger): }
\end{aligned}
$$

$\begin{array}{ll}\text { 老婆（乘客 } & \text { 别看手机了, 行吗? } \\ \begin{array}{ll}\text { Lăopó } \\ \text { (chéngkè): }\end{array} & \begin{array}{l}\text { bié kàn shǒujīle, xíng } \\ \text { ma? }\end{array} \\ \begin{array}{l}\text { Wife } \\ \text { (passenger): }\end{array} & \begin{array}{l}\text { Don't look at your } \\ \text { cellphone anymore, } \\ \text { can you? }\end{array}\end{array}$

(Duration 11:50)

Example (1) is an imperative sentence. In terms of function, it is a weak category imperative that expresses a request, marked with the word 请 qing 'please, please' at the beginning of the sentence. Example (2) includes the strong category of reprimanding imperative sentence type. The speaker (wife) admonishes the listener (husband) to stop looking at his cell phone.

Research on imperative sentences was also carried out by several researchers. Wang (2016) conduct an analysis of Imperative Sentences in (大唐西域记 dàtángxīyùjì Great Tang Notes). The discussion discusses imperative sentence structure and sees its changes. Hu (2018) carried a research about comparative analysis of imperative sentences in (发展汉语 fāzhăn hànyǔ) and (汉语教程 hànyǔ jiàochéng) examines the comparison of imperative sentence forms and functions in the two learning materials. (Murdiana et al., 2019) studied the syntax analysis on imperative sentences in suicide squad movie script. The analysis was on the function of imperative sentences in communication in the movie.

In line with the research above, this study analyzes imperative sentences which are specifically focused on the function of imperative sentences. Unlike previous studies, this study uses Zhang's theory and the 2019 "The Captain" movie as the source of data in this study. This movie tells about the incident of the Sichuan flight 8633 and the use of imperative sentences found in conversations between aircraft officers and other related 
parties so that the functions of the imperative sentences found are of course more diverse and the words used tend to be different from previous researchers.

\section{METHODS}

This article used a qualitative descriptive study. According to (Sukmadinata, 2011), qualitative descriptive research is aimed at describing and describing existing phenomena, both natural and human engineering, which pay more attention to characteristics, quality, linkages between activities. The data source of this research was obtained from a Chinese movie, namely "The Captain". The data in this study are imperative words and sentences contained in "The Captain" movie.

Researchers used two kinds of data collection techniques, namely listening techniques and note taking techniques. The listening technique is used to listen to language usage. The term listening here is not only limited to spoken language but also the use of written language. The note-taking technique means recording several forms that are relevant to research from the use of written language (Mahsun, 2005). The data analysis technique used in this study was the qualitative analysis proposed by (Miles et al., 2014). The first step the researcher took was to find data sources by downloading "The Captain" movie on the internet. Then the researcher listens to the conversation and marks the imperative words/sentences contained in the movie. The final step after listening to conversations in the movie is to note the imperative sentences contained in the movie, which will then be classified based on their function. Finally, conclude the results of the discussion.

This study uses the Zhang theory, Zhang (2014) divides imperative sentences into 3 main categories based on the tone of speech, namely strong, neutral and weak which distinguish the function of each imperative sentence. $\mathrm{He}$ argues that the strong imperative sentence has 4 functions to give instructions, command, admonish and threaten. Neutral imperative sentences have 6 functions, namely giving suggestion, advice, permission, reminding, entertaining and showing politeness. Furthermore, the weak imperative sentence has 3 functions to express asking, requesting and begging.

\section{RESULT AND DISCUSSION}

Researchers found 281 imperative sentences in "The Captain" movie with a different number of each imperative sentence function. To clarify the function of imperative sentences in "The Captain" movie, the researcher presents the data in the form of the chart below:

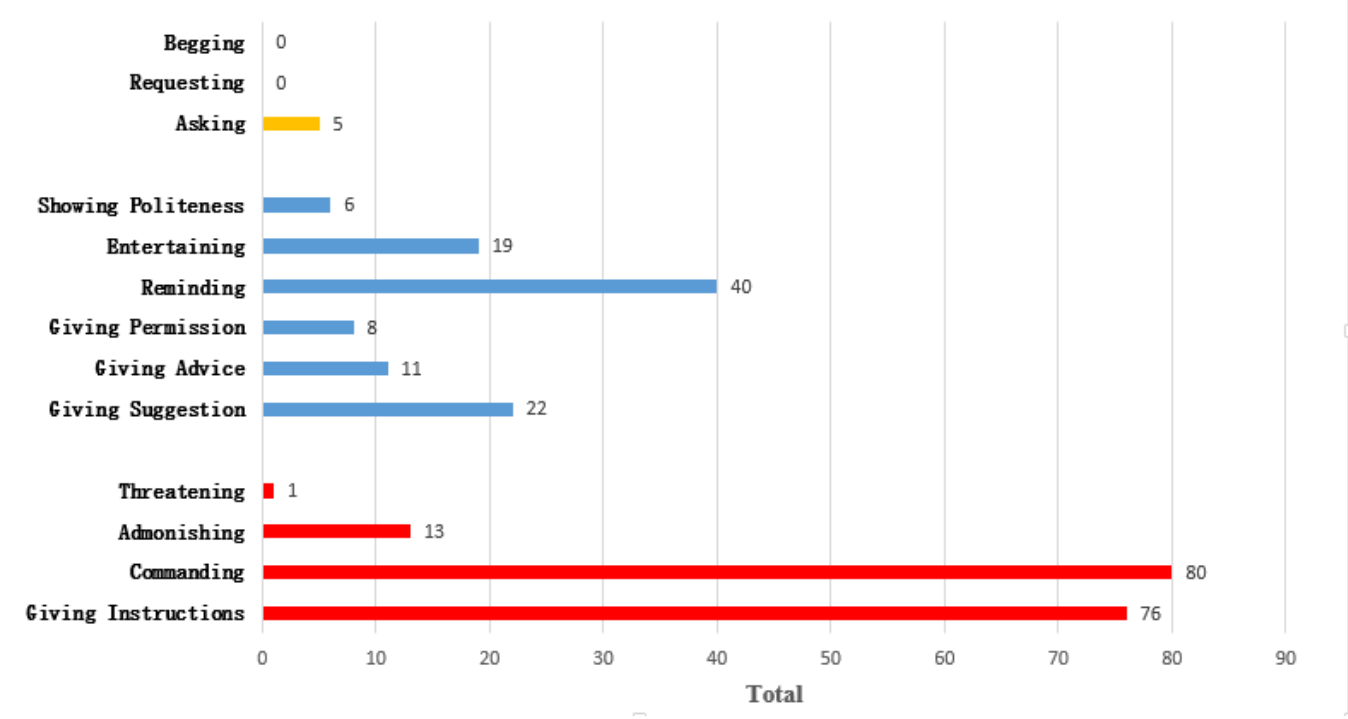

Chart 2. The function of the imperative sentence in "the captain" movie 


\section{Strong Category Imperative Sentences}

The use of imperative sentences in this category seems stronger, the speaker asks the listener to do something and does not provide a choice. Speakers often use a firm, direct tone to influence the will of the listener, and levels of politeness are relatively low. The strong category imperative sentence has 4 functions to give instructions, command, admonish and threaten.
The following is a table of the number of uses of the imperative sentence function in the strong category in "The Captain" movie. Table 1 shows the functions of imperative sentences "commanding" and "giving instructions", which are mostly found in "The Captain" movie, namely 80 and 76 . Furthermore, there are 13 "admonishing" function. Meanwhile, there is only one "threatening" function in "The Captain" movie.

Table 1. Strong Category Imperative Sentences in "The Captain" Movie

\begin{tabular}{|c|l|c|}
\hline No & Imperative Function & Total \\
\hline 1 & Giving Instructions & 76 \\
\hline 2 & Commanding & 80 \\
\hline 3 & Admonishing & 13 \\
\hline 4 & Threatening & 1 \\
\hline
\end{tabular}

\section{a. Giving Instructions Function}

The speaker gives direct instructions to the listener, mostly in formal communication, serious situations such as organizing assignments, military training, commando operations, training programs and official duties.

Data 1

民航局主任 : 今天上午七点到九点之间, 有个强对流云才将会对经过该区域的航路产生比较大的影响。 mínháng jú zhǔrèn : jīntiān shàngwǔ qī diăn dào jiǔ diăn zhījiān, yǒu gè qiáng duìliú yún tuán jiāng huì duì jīngguò gāi qūyù de hánglù chănshēng břjiào dà de yǐngxiăng.

Civil Aviation Administration Director : There will be clouds Between 7 to 9 A.M. this morning which affecting the aircraft trajectory area.

王默: 密切留意这段时间进出藏的航班!

wángmò: mìqiè liúyì zhè duàn shíjiān jìnchū zàng de hángbān! Wang Mo: Pay more attention to the flights to and from Tibet. 王默: 做好航班取消或者延误的准备!

wángmò: zuò hăo hángbān qǔxiāo huòzhě yánwù de zhǔnbèi!

Wang Mo: Be prepared for departure delays and cancellations.

(The Captain, 2019 : 05:55-06:12)

Data 1 shows the Conversation of the Director of the Beijing Civil Aviation Administration to all air traffic administrators before the departure of the Sichuan 8633 flight. They had anticipated a cloud that would affect the flight at that time. After hearing the report, Wang Mo, the administrative head of the southwest air traffic control room, immediately conveyed this to his members. Wang Mo said: “密切留意这段时间进出藏的航班 mìqiè liúyì zhè duàn shíjiān jìnchū cáng de hángbān" (pay more attention to flights to and from Tibet). It is included in the imperative sentence characterized by the presence of the verbal phrase "密切留意 mìqiè liúyì" (pay more attention). In this case, Wang Mo as the chairman was giving instructions to the members. Social relations between speakers that trigger the function of imperative sentences provide instructions, namely leadership to subordinates.

\section{b. Commanding Function}

The speaker directly assigns or instructs the listener to do something, which mostly occurs in informal, casual events or in areas of 
everyday life.

$\begin{array}{ll}\text { Data } 2 & \\ \text { 机器 } & \text { : 请吹气 ! } \\ \text { jīqì } & \text { : quing chuīqì ! } \\ \text { Engine } & \text { : Please exhale! } \\ \text { 机器 } & \text { : 正常。 } \\ \text { jīqì } & \text { : zhèngcháng! } \\ \text { Engine } & \text { : Normal! }\end{array}$

Data 2 shows the existence of a pilot's health check before making a flight using the engine. The machine ordered the second captain to exhale, to see the condition of his body. The machine gives the command: "请吹气quing chuīqì" (exhale please), then the machine detects the second captain's breath and the result is normal. In this case, the Speaker (machine) directly commands the listener to do something. The imperative sentence is indicated by the presence of the particle "请qǐng" (please), followed by the verbal phrase "吹气 chuīqì" (exhale).
(The Captain, 2019 : 05:25-05:31)

\section{c. Admonishing Function}

The speaker immediately rebukes the listener for doing something, which often happens in contexts where the listener has certain words and actions that make the speaker dissatisfied. From the perspective of the text in which the imperative sentence occurs, there are often some slang, derogatory words or words that indicate the speaker's negative emotions etc.

Data 3.

航空爱好者:你们还记得2005年太阳神522幽灵航班吧?

hángkōng àihàozhě: nǐmen hái jìdé 2005 nián tàiyáng shén 522 yōulíng hángbān ba?

Aviation Buff: Did you remember the 2005 Helios 522 flight?

航空爱好者:飞机起飞之后没有自动加压，机舱上所有人很快就缺氧昏迷了。

hángkōng àihào zhě: fêijīi qǔfēi zhīhòu méiyǒu zìdòng jiā yā, jīcāng shàng suǒyǒu rén hěn kuài jiù quēyăng hūnmíle.

Aviation Buff: After the plane took off, there was no pressure automatically, everyone in the cabin immediately fell into a coma from lack of oxygen.

航空爱好者: 可是飞机设定了自动驾驶系统, 就这么一直飞, 到了雅典上空盘旋, 盘旋, 油 耗尽了。

hángkōng àihào zhě: kěshì fêijīi shè dìngle zìdòng jiàshǐ xìtǒng, jiù zhème yīzhí fēi, dàole yădiăn shàngkōng pánxuán, pánxuán, yóuhào jìn le.

Aviation Buff: But the plane was on autopilot, so it kept flying and hovering in the air, hovering until it ran out of fuel.

男航迷: 8633 氧气应该也不多了。

nán háng mí: 8633 yăngqì yīnggāi yě bù duōle.

Aviation Buff (Man): The oxygen of the 8633 aircraft is probably not that much anymore.

宅女航迷: (打男航迷)

zhái nŭ háng mí: (dă nánhángmí)

Aviation Buff (Woman): (hit that man)

男航迷: 我说的是实话。

nán háng mí: wǒ shuō de shì shíhuà.

Aviation Buff (Man): I just say the fact.

宅女航迷: 实话也(要)谨慎说！

zhái nŭ̉ háng mí: shíhuà yě (yào) jǐnshèn shuō!

Aviation Buff (Woman): (must) carefully speak even if it is a fact!

(The Captain, 2019 : 01:00:34-01:01:11) 
Data 3 shows the conversation of airplane fans in an apartment. One airplane fan brought up the case of a 2005 Helios 522 flight that failed. Aircraft enthusiasts also expressed their opinion that the Sichuan 8633 aircraft might not have much oxygen anymore. The airplane fan (woman) took offense at what her friend said and said “实话也要谨慎说 shíhuà yě yào jǐnshèn shuō" (must be careful in speaking even if it's a fact). An imperative sentence is characterized by the presence of the particle "要 yào" (must), followed by a verbal phrase "谨慎说 jǐnshèn shuō" (be careful in

Data 4

乘客: 我们就想见一下机长, 要不我们不 上车。

chéngkè: wǒmen jiù xiăngjiàn yīxià jī zhăng, yào bù wǒmen bù shàngchē.

Passenger: We just wanted to see the captain, otherwise we wouldn't take the pick up bus.

乘客: 知道吗? 行吧?

chéngkè: zhīdào ma? xíng ba?

Passenger: How? may i?

吴先生: 我们只想见一下机长, 要不我们不上车, 对吗?

wú xiānsheng: wǒmen zhǐ xiăngiàn yīxià jīzhăng, yàobù wǒmen bù shàngchē, duìma?

Mr. Wu: We just wanted to see the captain for a bit, otherwise we don't want to get on the pick-up bus, do we?

乘客们: 我们要见机长！

chéngkèmen: wǒmen yào jiànjī zhăng!

Passenger: We want to meet the captain!

Data 4 shows the passengers on the Sichuan 8633 plane have landed safely at the Chengdu airport. passengers gather around the plane. Several passengers asked to meet with the captain, one of them was Mr. Wu. He said: “我们只想见一下机长, 要] 我们不上车 wǒmen zhǐ xiăngjiàn yīxià jīzhăng, yào bù wǒmen bù shàngchē" (We just wanted to see the captain for a while, otherwise we didn't want to take the pick up bus). Mr. Wu conveyed his threat that if they were not granted a meeting with the captain, they would not take the pick-up bus. The sentence uttered by $\mathrm{Mr}$. Wu is an imperative sentence which has a threatening function, marked by the clause "我们只想见一下机长 wǒmen zhǐ xiăngjiàn yīxià jīzhăng" (we just wanted to meet the captain) followed by a link "要不 yàobù" (otherwise) as a liaison that emphasizes a threat. that trigger the imperative sentence function of friends).

\section{d. Threatening Function}

Speakers threaten listeners to do something and implied content often states or implies that the listener will be punished or suffer if he / she does not comply. From the perspective of the text in which the imperative sentence occurs, there are often words that indicate the speaker's strong or harsh actions. speaking). Social relations between speakers reprimanding, namely equal relations (fellow

(The Captain, 2019 : 01:38:01-01:38:16) 
Table 2. Imperative Sentences for Neutral Categories in "The Captain" Movie

\begin{tabular}{|c|l|c|}
\hline No & Imperative Function & Total \\
\hline 1 & Giving Suggestion & 22 \\
\hline 2 & Giving Advice & 11 \\
\hline 3 & Giving Permission & 8 \\
\hline 4 & Reminding & 40 \\
\hline 5 & Entertaining & 19 \\
\hline 6 & Showing Politeness & 6 \\
\hline
\end{tabular}

\section{a. Giving Suggestion Function}

The speaker advises the listener to do something and the decision to follow the suggestion is up to the speaker. There are often several particles that reflect the speaker's negotiating intentions or the particle "吧 ba" is often used, or uses the intonation in it.

Data 5

机长: 这团云可够大的。

jīzhăng: zhè tuán yún kě gòu dà de.

Captain: These clouds can be quite large.

机长:去的时候咱们可以上高度避开云的前端。

jīzhăng: qù de shíhòu zánmen kěyǐ shàng gāodù bì kāi yún de qiánduān.

Captain: When we go, we can increase the height to avoid these clouds.

机长: 等我们回来的时候, 它也走了。

jīzhăng: děng wǒmen huílái de shíhòu, tā yě zǒule.

Captain: Then when we come back, this cloud is gone.

(The Captain, 2019: 07:26- 07:35)

Data 5 shows the Pilot who was in a meeting before making the flight. The captain is also aware of a large cloud that will affect their flight. The captain said: “去的时候咱们可以上高度避开云的前端 qù de shíhòu zánmen kěyǐ shàng gāodù bì kāi yún de qiánduān" (When we go, we can raise the altitude to avoid this cloud). The captain's advice was to "raise the altitude while flying" in order to avoid the cloud. The words of the captain belong to the neutral category imperative sentence which has the function of "giving advice" which is indicated by the verbal phrase "可以上高度 kěyǐ shàng gāodù" (can raise the height). The social relations between speakers that trigger the imperative sentence function provide suggestions, namely equal relations (among colleagues).

\section{b. Giving Advice Function}

The speaker asks the listener to do something, something very important, but subconsciously thinks the listener is not paying enough attention or is worried that the listener will forget. Particles to emphasize the tone that are often used in sentences, such as "千万 qiānwàn" (must), "务必 wùbì" (required), "可 kě" (must) and so on. The researcher found that the function of giving advice in this movie was marked by the words "一定 yīdìng" (must) and "特别 tèbié" (special).

Data 6

导游（乘客）:咱们到了拉萨之后，因为那里的海拔比较高，有 3600 多米。

dăoyóu (chéngkè): zánmen dàole lāsà zhīhòu, yīnwèi nàlǐ dì hăibá bǐjiào gāo, yǒu 3600 duōmǐ.

Tour Guide (passenger): After we arrived in Lhasa, because the altitude there is relatively high, about 3,600 meters.

游客（乘客）:我们呢，还想在布达拉宫 
跳广场舞呢!

yóukè (chéngkè): wǒmen ne, hái xiăng zài bù dá lā gōng tiào guăngchăngwǔ ne!

Tourist (passenger): We still want to dance at the Potala Palace!

导游 (乘客): 阿姨, 一定不能剧烈 活动!

dăoyóu (chéngkè): āyí, yīdìng bùnéng jùliè huódòng!

Tour Guide (passenger): Madam, you have to avoid such activities!

(The Captain, 2019:10:19-10:28)

Data 6 shows the passengers waiting at the airport for ticket inspection. Likewise with one of the passengers on the Sichuan 8633 plane, namely the tour group. After the tour guide distributed their tickets, he explained about the conditions in Lhasa. One of the group members, a mother wants to dance at the Potala Palace. Hearing this, the tour guide immediately said: “阿姨, 一定不能剧烈活动 āyí, yīdìng bùnéng jùliè huódòng" (Mom, should avoid such activities) meaning the tour guide emphasizes the mother to avoid activities (dancing at the Potala Palace). In this case the imperative sentence is marked with the word "一定 yīdìng" (must), followed by the verbal

\section{Data 7}

保安: 请排队接受防爆检查!

băo'ān: qǔng páiduì jiēshòu fángbào jiănchá!

Security Guard: Please line up for a check!

保安: 来, 可以进了!

băo'ān: lái, kěy̌̌ jìnle!

Security Guard: Come on, (you) can enter!

Data 7 shows passengers doing security checks at the entrance before entering the airport. After the inspection was over, the security guard broke the seal and said: “来，可以进了 lái, kěyǐ jìnle” (come, you can enter). In addition, the imperative sentence above is also marked with the verb "来 lái" (come) at the beginning to indicate direction, followed by the verbal phrase "可以进了 kěy̌ jìnle" (may enter). phrase "不能剧烈活动 bùnéng jùliè huódòng" (not to do such activities). The social relations between speakers that trigger the imperative sentence function of giving advice, namely the relationship between leaders and subordinates.

\section{c. Giving Permission Function}

Speaker subjectively gives permission or agrees to the listener to do something. This appears frequently in dialogue responses. Particles that are often used such as "吧 ba" or the word "可以 kěyǐ (may)".

(The Captain, 2019:10:11-10:15)

d. Reminding Function

The speaker reminds the listener to do something and uses the words "小心 xiăoxīn careful", 当心 dāngxīn beware, 留心 liúxīn careful, 注意 zhùyì pay attention, 留神 liúshén careful "and others in sentences to remind the listener to be aware of what that occurs, showing the speaker's concern or concern for the listener.

Data 8

报告员: 前往拉萨的旅客请注意, 您乘坐的3U8633次航班很快就要起飞了。 bàogào yuán: qiánwăng lāsà de lǚkè qǔng zhùyì, nín chéngzuò de 3 U8633 cì hángbān hěn kuài jiù yào qứēi le.

Broadcasting Office: Attention passengers traveling to Lhasa, flight 3 U8633 will be taking off soon.

(The Captain, $2019: 16: 28-16: 35)$ 
Data 8 shows the passengers lined up to get on the plane. They heard an announcement sound that read: "前往拉萨的旅客请注意, 您乘坐的

3U8633 次航班很快就要起飞了 qiánwăng lāsà de lǘkèqǐng zhùyì, nín chéngzuò de 3U8633 cì hángbān hěi kuài jiù yàn traveling to Lhasa, plane 3U8633 will be taking off soon). The imperative sentence is marked with the verbal phrase "请注意quing zhùyì" (please pay attention). The announcement includes the imperative sentence neutral category used to remind passengers to get ready to board the plane.

\section{e. Entertaining Function}

The speaker coaxes or entertains the listener into doing something, the tone is soft, and often expresses the speaker's care and affection for the listener.

Data 9

机长: 多可爱的小狗啊! 怎么有人说扔就 扔呢?

jīzhăng: duō kě'ài de xiăo gǒu a! zěnme yǒurén shuō rēng jiù rēng ne?

Captain: How could anyone ignore a cute animal like you?

机长: 好, 行了, 再坚持点两次眼睛就 好了!

jīzhăng: hăo, xíngle, zài jiānchí diăn liăng cì yănjīng jiù hăole!

Captain: Alright, it's already, hold on two more times, your eyes will heal soon!

(The Captain, 2019:04:04-04:15)

Data 9 shows the Captain was treating his pet dog before going to work. He put the medicine on the dog's eye and said: “再坚持点两次眼睛就好了 zài jiānchí diăn liăng cì yănjīng jiù hăole" (hold on two more times, your eyes will heal soon). The sentence spoken by the captain belongs to the neutral category imperative sentence which has an entertaining function marked by the verbal phrase "再坚持点 zài jiānchí diăn" (hang on).

f. Showing Politeness Function

This type of imperative sentence is

Data 10

乘务长: 这是您要的粥。

chéngwùzhăng: zhè shì nín yào de zhōu.

Chief flight attendant: This is your porridge.

吴先生: 我不喜欢喝粥呀, 我特别喜欢吃小面！

wúxiānsheng: wǒ bù xǐhuān hē zhōu ya, wǒ tèbié xǐhuān chī xiăo miàn!

$\mathrm{Mr}$. Wu: I don't like porridge, I want to eat noodles.

乘务长: 马上。

chéngwùzhăng: măshàng.

Chief flight attendant : Immediately.

乘务长: 吴先生, 您的小面, 请慢用!

chéngwùzhăng: wúxiānsheng, nín de xiăo miàn, qǔng màn yòng!

Chief flight attendant: Mr. Wu, here are your noodles, please enjoy!

(The Captain, $2019: 28: 30-28: 47$ ) special, the subject of the conversation does not care whether the other party takes this action, that is, the conceptual meaning of this type of imperative sentence has been softened, and the interpersonal meaning is very prominent and sounds relatively polite. In Modern Chinese, the many uses of functions denoting politeness are indicated by the words “有空再来玩 yǒu kòng zàilái wán”, “请留步 qǔng liúbù”, “不送 bù sòng”, “再见 zàijiàn”, “拜托 bàituō”, “慢点儿 màn diănr ”,“劳驾 láojià ”,“回聊 huíliáo ”、“再会 zàihuì ”etc. 
Data 10 shows the chief flight attendant who delivered food to $\mathrm{Mr}$. $\mathrm{Wu}$, who was a guest of the airline's business class. After delivering Mr. Wu's food (noodles), the flight attendant said:

“吴先生，您的小面，请慢用wúxiānsheng， nín de xiăomiàn, qǔng mànyòng" ( $\mathrm{Mr}$. $\mathrm{Wu}$, here are your noodles, please enjoy). In the sentence there is a verbal phrase "请慢用qǐng mànyòng" (please enjoy) which was uttered by the head of the flight attendant to show his politeness.

\section{Weak Category Imperative Sentence}

Weak category imperative sentences have 3 functions to express asking, requesting and begging. Table 3 shows the functions of the imperative sentences that are most commonly found in the weak category is expressing a request of 5 pieces. As for the functions "requesting" and "begging" are not found in "The Captain" movie because this movie mostly tells about the incident of the Sichuan flight number 8633. In this movie tells about how the communication of captains, officers, flight attendants, passengers and other parties.

Table 3. Imperative Sentences for Weak Category in "The Captain" Movie

\begin{tabular}{|c|c|c|}
\hline No & Imperative Function & Total \\
\hline 1 & Asking & 5 \\
\hline 2 & Requesting & 0 \\
\hline 3 & Begging & 0 \\
\hline
\end{tabular}

\section{a. Asking Function}

The speaker makes his request to the listener politely, hoping the listener can do what he wants. Polite words that are often used in sentences, such as "请 qǐng please",

the listener with a respectful manner that encourages the listener to take the action the speaker wants.

Data 11

保安：麻烦签一下字！

băoān : máfan qiān yíxià zi!

Officer : Please sign here for a moment!

(The Captain, 2019 : 14:16)

Data 11 shows the security officer who asked for the signature of the chief flight attendant. The officer said: “麻烦签一下字 máfan qiān yíxià zi” (please sign here briefly). The imperative sentence is indicated by the presence of the particle "麻烦 máfan" which expresses a request. Furthermore, it is denoted by the verbal phrase “签一下字 qiān yíxià zi" (brief signature here). The social relations between speakers that trigger the imperative sentence function expressing demand, that is, equal relations (among colleagues).

a. Requesting Function (not found in "The Captain" movie)
"劳驾 láojià (please help)", "行个方便 xínggè fāngbiàn (please help)", "帮帮忙 bāngbāng máng (please help)", " 麻烦你 máfan nǐ (please help) "etc. The speaker hopes to impress

b. Begging Function (not found in "The Captain" movie)

\section{CONCLUSION}

Researchers found 281 imperative sentences in the 2019 Chinese movie "The Captain" (中国机长 Zhōngguó Jīzhăng).

1. The most widely used imperative function is the command function, which is 80 units. Meanwhile, the least function found was threatening function as much as 1 (one). The function of commanding is more dominant than other functions and is found mostly in conversations between officers and passengers, flight attendants to passengers, communication between officers and other related parties. The commanding function is also mostly found in the conversations of officers, especially when they are facing an emergency situation. Meanwhile, the words used by both the flight attendants and the captain as a whole show respect and 
courtesy so that there is very little threatening function to be found in this movie.

2. The researcher did not find the begging function and begging function in this movie. This is because this movie mostly tells about the incident of Sichuan flight number 8633 , including the service of the aircraft officers and the confidence of the officers in facing an emergency situation at that time. This movie also tells about how the captain, officers, flight attendants, passengers and other related parties communicate.

It is recommended that readers who are interested in conducting research on imperative sentences can expand their study and object of research by discussing other imperative sentences. In addition, "The Captain" movie can be used as a reference for other research objects.

\section{REFERENCES}

Alwi. (2003). Tata Bahasa Baku Bahasa Indonesia (3rd ed.). Jakarta: Balai Pustaka.

Chaer, A. (2007). Linguistik Umum. Jakarta: Rineka Cipta.

Cleveresty, T. B., \& Afrina, U. (2020). Representasi Nilai Budaya Tiongkok dalam Kalimat Sapaan Bahasa Mandarin 吃饭了吗? Chīfàn Le Ma? Metahumaniora Journal, 10(2), 230-238.

Effendy. (1986). Dimensi Dimensi Komunikasi. Bandung: Alumni.

Hu. (2018). Analisis Perbandingan Kalimat Imperatif dalam Fazhan Hanyu dan Hanyu Jiaocheng (Master Thesis). Huazhong Shifan Daxue, Wuhan.

IYS, (2019), Kisah Nyata Pilot Liu Chuanjian Dapat Penghargaan Rpll Miliar karena Selamatkan 119 Penumpang Karena Kaca Pesawat Pecah. Retrieved April 20, 2020 from koranseruya website: https://koranseruya.com/65885.html
Jing, Y., Gao, S., \& Dong, Z. (2010). Analysis On the Cultivation of the Humanistic Qualities of College Students by Social History Education. International Conference on Optics, Photonics and Energy Engineering (OPEE), 99-102.

Kridalaksana. (2001). Kamus Linguistik. Jakarta: Gramedia Pustaka Utama.

Li, Dejin. (2012). Waiguoren Shiyong Hanyu Yufa (2rd ed.). Beijing: Beijing Yuyan Daxue Chubanshe.

Mahsun. (2005). Metode Penelitian Bahasa. Jakarta: PT Raja Grafindo Persada.

Mulatsih, M. V. E., \& Putri, B. A. (2020). Kartinis Teacher Concept and Principles in Letters of a Javanese Princess. Journal of Language and Literature, 20(2), 212-220.

Miles, M., M., H. A., \& Saldana, J. (2014). Qualitative Data Analysis: A Methods Sourcebook (3rd ed.). Sage Publisher.

Murdiana, S., Nugraheni, Y., \& Hardianti, D. (2019). Analisis Sintaksis pada Kalimat Imperatif di Naskah Film Suicide Squad. Proceeding Seminar Nasional Mahasiswa Unimus Humaniora \& Religion.

Silalahi, I. N. S. br, \& Halimi, S. S. (2020). Use of Video in Teaching Grammar to PreSecondary Students. International Review of Humanities Studies, 5(2), 548-558.

Sofyan, A. N. (2015). Frasa Direktif yang Berunsur di, dari, dan untuk dalam Bahasa Indonesia: Kajian Sintaktis dan Semantis. Sosiohumaniora Journal, 8(3).

Sugiyono. (2008). Metode Penelitian Kuantitatif Kualitatif dan $R \& D$. Bandung: Alfabeta.

Suhardi. (2008). Sintaksis. Yogyakarta: UNY Press.

Sukmadinata, N. S. (2011). Metode Penelitian Pendidikan. Bandung: Remaja Rosadakarya.

Wang. (2016). Analisis Kalimat Imperatif dalam Datang Xiyouji (Master Thesis). Xinjiang Shifan Daxue, Xinjiang.

Zhang. (2014). Xiandai Hanyu Qishiju Renji Gongneng Yanjiu. Beijing: Zhongguo Shehui Kexue Chubanshe, [Online] 